\title{
Repositories of Open Educational Resources: An Assessment of Reuse and Educational Aspects
}

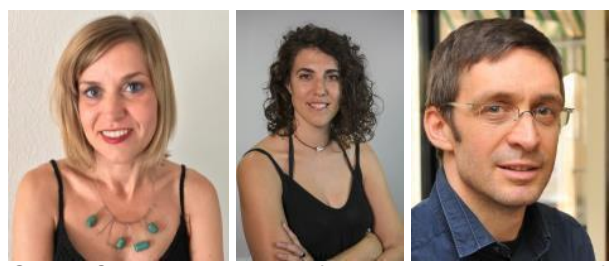

Gema Santos-Hermosa ${ }^{1}$, Núria Ferran-Ferrer ${ }^{2}$, and Ernest Abadal ${ }^{3}$

1,3University of Barcelona, 1,2Open University of Catalonia

\begin{abstract}
This article provides an overview of the current state of repositories of open educational resources (ROER) in higher education at international level. It analyses a series of educational indicators to determine whether ROER can meet the specific needs of the education context, and to clarify understanding of the reuse of open educational resources (OER) provided by ROER. The aim of the study is to assess ROER by combining these two perspectives, and to form a basis for discussion among the universities that are responsible for these repositories.

The method was based on content analysis and consisted of two phases: an exploration of international sources, and an analysis of 110 ROER using the proposed set of indicators. The results focus on data from the analysis of ROER websites and some models of good practices. They are presented according to three core dimensions for evaluating ROER: general factors to establish types of ROER, a focus on drivers for OER reuse, and a focus on educational aspects. It was found that most of the ROER that included one or more of the proposed reuse indicators were created exclusively for educational resources. Educational aspects are not yet firmly embedded into ROER. The few repositories that seem to have successfully included them are those that provide other educational metadata and use educational standards.
\end{abstract}

Keywords: repositories, open educational resources, OER, evaluation, reuse, higher education

\section{Introduction}

In the past decade, the Open Educational Resources (OER) movement has gained ground and expanded exponentially. Previously, there were only localized OER initiatives; now OER are recognized and 
supported by key international institutions, governments and funders worldwide. Although OER have become more significant worldwide and their availability and use have expanded, the movement has still not achieved its full potential and entered the mainstream education system (Ochoa \& Duval, 2009; Dickev \& Dicheva, 2012; European Commission, 2013a).

In February 2015, the collaborative report “OER Strategy Development” (Allen, Browne, Forward, Green, \& Tarkowski, 2015) provided a concise analysis of the current state of the OER movement and became a roadmap to identify specific strategies to achieve the "real adoption" of OER (understood as taking advantage of the rights and permissions granted by OER for use and reuse).

According to the report, current platforms that enable the management, discovery, use, and reuse of open content are inadequate and not very well-known; resources are found in a wide range of formats, and repositories are varied and generally do not include common search terms or metadata. For this reason, a study on the extent to which existing OER repositories (ROER) promote the discovery, use, and reuse of resources may lead to improvements in the adoption and impact of OER.

The OER movement in Europe has led many universities to rethink their institutional policies, and consider how to innovate in higher education teaching and learning practices. In its Opening up Education initiative, the European Commission (2013a) observed that "stimulating supply and demand for high-quality European OERs is essential for modernizing education" and that "OER must become more visible and accessible to all citizens." One of the key transformative actions proposed is to improve the visibility of quality OER produced in the EU by 2020, through the development of open digital ROER using investment funds.

Evidence (European Commission, 2013b) shows that greater exploitation of OER would increase access to education, and the development of quality educational standards would have a positive effect. Consequently, ROER should include educational aspects and metadata so that the most relevant resources are classified and can be retrieved by the main users: teachers and students.

This study takes into account a series of educational indicators that determine whether ROER can meet the specific needs of the education context. It also defines the scope of ROER and proposes a series of indicators to analyze them, and particularly to clarify understanding about the reuse of OER provided by ROER. Consequently, this study could help to determine what can be done to improve ROER and may become a basis for discussion among universities and institutions responsible for these repositories. This is deemed essential, since ROER can make a substantial contribution towards achieving the goals of the Europe 2020 strategy: quality and relevance in higher education (European Commission, 2014).

\section{Background}

Global knowledge and research in OER is increasing. This topic has aroused the interest of researchers, as OER could make a strong contribution to improving education and fostering openness. 
One of the main themes of OER research is OER and technology, and repositories in particular (Zancanaro, Todesco, \& Ramos, 2015). A pioneering, complete overview of ROER that examined their main features was conducted by Tzikopoulos, Manouselis, \& Vuorikari (2007). Several other studies focused on guidelines for developing ROER (Organisation for Economic Co-Operation and Development [OECD], 2007; UNESCO, 2011), their structure (McGreal, 2011), operational aspects and a quantitative analysis of repositories (Ochoa \& Duval, 2009), additional services that they might provide (Zervas, Alifragkis, \& Sampson, 2014; de los Arcos, Farrow, Perryman, Pitt, \& Weller, 2014) and a holistic approach to quality assurance (Atenas \& Havemann, 2013; Clements, Palowski, \& Manouselis, 2015). Similarly, a recent study focused on the institutional promotion of OER through repositories (Castaño, Punie, Inamorato, Mitic, \& Morais, 2016) and details of ROER have been gathered in international directories, such as the OER World Map (D'Antoni, 2013), OER Repositories World Map (Atenas \& Havemann, 2014) and OER Atlas (Neumann \& Muuß-Merholz, 2016).

However, none of these studies specifically refers to the reuse and educational aspects of ROER: these two unresolved issues merit particular attention in our research.

Wiley (2000) considered that any digital resource could be reused to support learning, and subsequent studies have stressed the importance of reuse. However, they have also recognized the great difficulty in finding evidence of reuse (Orr, Rimini, \& Van Damme, 2015), the still insufficient analyses (de los Arcos et al., 2014), and the "problem of remix" (Wiley, Bliss, \& McEwen, 2014). The most common discussion framework has been focused on user surveys (McKerlich, Ives, \& McGreal, 2013; Camilleri, Ehlers, \& Pawlowski, 2014) and tracking OER usage (Pegler, 2011). A couple of studies specifically address the connection between reuse and ROER as a key theme that represents one type of activity within a repository (Atenas \& Havemann, 2013), or link reuse to the creation of personal spaces (Cohen, Reisman, \& Sperling, 2015). Nevertheless, ROER's current "predisposition" to reuse has not been considered. For this reason, the present research examines opportunities provided by ROER that facilitate reuse of OER.

Regarding educational issues, studies have mainly focused on benefits, challenges, and limitations associated with OER (Wiley et al., 2014), their creation and distribution (open textbooks, repositories, OCW courses and MOOCs), and their important role in open education (Lane \& McAndrew, 2010; UNESCO, 2011; OECD, 2015). There are many studies on metadata evaluations of ROER (Bueno-de-laFuente, Hernández-Pérez, Rodríguez-Mateos, Méndez-Rodriguez, \& Martín-Galán, 2009), but these adopt a formal and technological perspective rather than analyze the educational relevance of ROER (Rodríguez, Dodero \& Sánchez-Alonso, 2011; Atenas \& Havemann, 2013). Therefore, the current study aims to explore how ROER support teaching and learning, based on educational requirements.

We are aware of the connection between reuse and educational aspects, and understand that reuse can be more difficult because the educational design is rarely visible (Wiley et al., 2014). Therefore, this is the first review that integrates both perspectives in ROER. It also provides an overview of the current state of ROER in higher education.

As some aspects of ROER are underdeveloped, a distinctive, value-added framework is becoming indispensable. Since reuse and educational aspects in ROER still pose certain challenges, we propose the following research questions: 
1. What are ROER and what are their main features?

2. What features can be found in ROER that promote reuse and educational aspects?

3. How developed are ROER with respect to reuse and educational aspects?

\section{Method}

The method used in this study was based on content analysis (Krippendorff, 1980) and consisted of two phases:

1. Exploration of international and specialized sources about ROER, and selection of the ROER population to be analyzed.

2. Analysis of the ROER population using a proposed set of indicators, divided into three main categories that were directly related to the research questions.

\section{Selecting a Population}

In order to select ROER for analysis, the following sources were used: the Registry of Open Access Repository (ROAR), the Directory of Open Access Repositories (Open DOAR), the portal Open Education Europe, a report on the State of the Art by the Educational Repositories Network (EdReNe), and other literature on the subject.

After retrieving a total of 1,186 repositories of "learning objects" or "educational resources," a population of 110 ROER was selected using the following criteria (Figure 1):

A. A higher education (HE) level of education, or HE combined with other levels.

B. Updated from 2011 onwards, and currently functioning.

C. Repositories with specific OER collections.

D. Repositories containing at least 50 OER. 


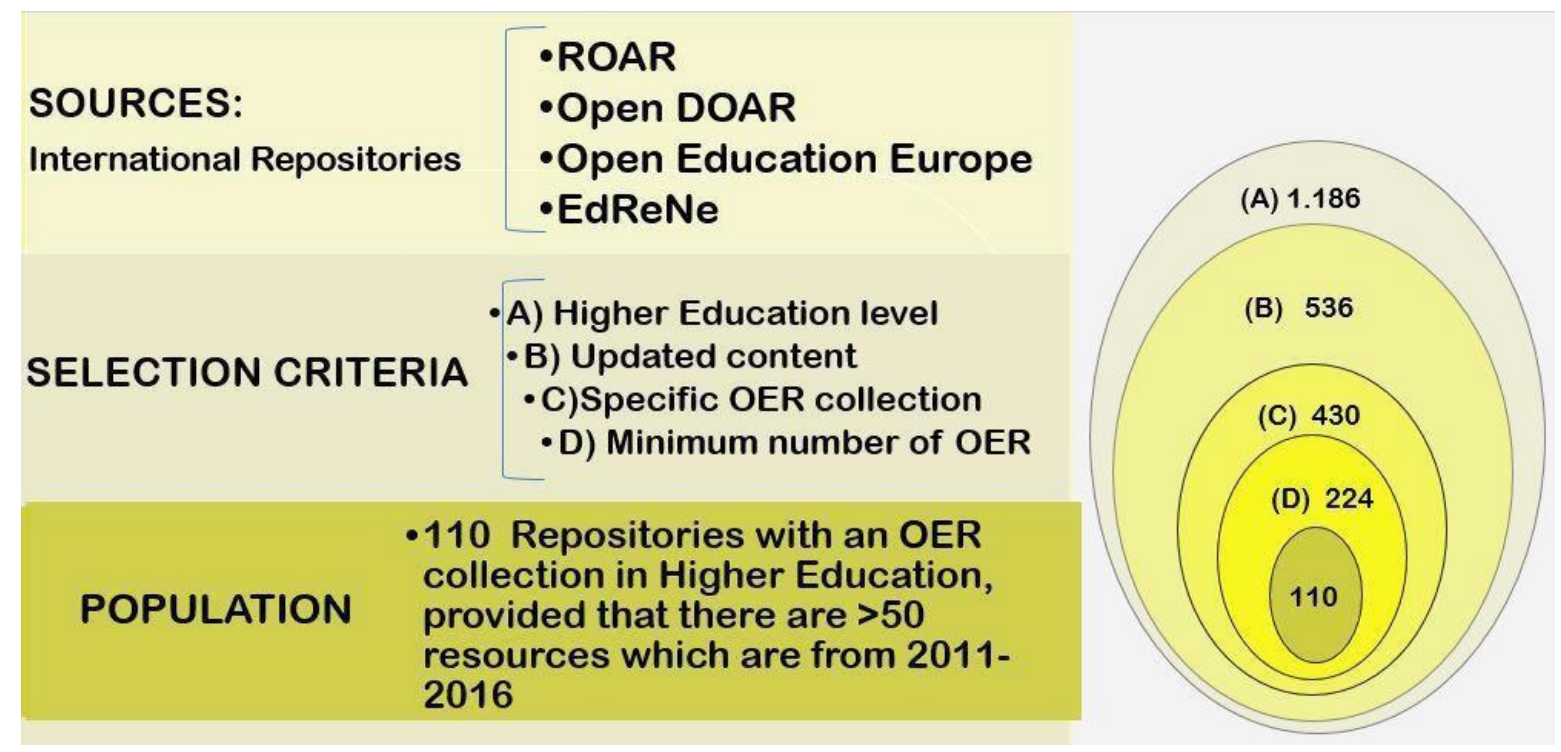

Figure 1. Selection of the ROER population (Santos-Hermosa, Ferran-Ferrer, \& Abadal, 2015).

\section{Core Dimensions and Indicators}

Repositories tend to be evaluated using institutional factors that are based on institutional needs and strategies (Westell, 2006; Serrano, Melero \& Abadal, 2014). However, considering that ROER's particular requirements differ from those of traditional digital repositories (Cervone, 2011), other aspects could be taken into account.

The current study proposes three core dimensions for evaluating ROER: general/descriptive factors to establish types of ROER, a focus on drivers for OER reuse, and a focus on educational aspects. These categories are broken down according to specific indicators. 


\section{Category 1: General indicators: Types and technology.}

Table 1

\section{ROER Types and Technology}

\begin{tabular}{|c|c|c|c|}
\hline CRITERIA & INDICATORS & DESCRIPTION AND VALUES & REASONING \& REFERENCES \\
\hline \multirow{2}{*}{$\begin{array}{l}\text { OER stored wholly or } \\
\text { partially }\end{array}$} & Exclusive ROER & $\begin{array}{l}\text { Only contains learning resources, created } \\
\text { especially for OER }\end{array}$ & \multirow[t]{2}{*}{$\begin{array}{l}\text { In-house indicator that might identify } \\
\text { particular patterns in ROER. }\end{array}$} \\
\hline & Hybrid ROER & Contains research and learning resources & \\
\hline \multirow{2}{*}{ Discipline } & Multidisciplinary & Stores OER from all disciplines & \multirow{2}{*}{$\begin{array}{l}\text { Indicator for discovering the issues } \\
\text { adressed in ROER: broader vs. subject } \\
\text { domain (Sampson, Zervas \& Sotiriou, } \\
\text { 2013) }\end{array}$} \\
\hline & Thematic & Stores OER from one or specific disciplines & \\
\hline \multirow{2}{*}{$\begin{array}{l}\text { Person responsible or } \\
\text { creator }\end{array}$} & Institutional & $\begin{array}{l}\text { Created by universities, foundations or } \\
\text { institutes }\end{array}$ & \multirow{3}{*}{$\begin{array}{l}\text { Indicators about authorship and origin } \\
\text { have been considered in studies } \\
\text { evaluating ROER (Tzikopoulos, } \\
\text { Manouselis \& Vuorikari, 2007; Atenas \& } \\
\text { Havemann, 2013) }\end{array}$} \\
\hline & National & $\begin{array}{l}\text { Funded by governments, national } \\
\text { organizations or consortia }\end{array}$ & \\
\hline \multirow[t]{2}{*}{ Geographical origin } & Continent & $\begin{array}{l}\text { Africa, America (USA \& South America), Asia, } \\
\text { Australia \& Europe }\end{array}$ & \\
\hline & Country & Name of the country & Bueno-de-la-Fuente et al., 2009 \\
\hline Software/platform & Name of software & $\begin{array}{l}\text { Identifies the software for repositories } \\
\text { (Dspace, Eprints, Fedora, etc) or other kinds } \\
\text { of platforms (Moodle, html5, CMS, Drupal) }\end{array}$ & \multirow{2}{*}{$\begin{array}{l}\text { Although an institutional approach is not } \\
\text { entirely relevant, general indicators } \\
\text { related with software and metadata } \\
\text { have been considered (Bueno-de-la- } \\
\text { Fuente et al., 2009; UNESCO, 2011; } \\
\text { Pegler, 2011; Barrueco et al., 2014). }\end{array}$} \\
\hline Metadata standard & $\begin{array}{l}\text { Name of the } \\
\text { metadata } \\
\text { standard }\end{array}$ & $\begin{array}{l}\text { Identifies the metadata standard system } \\
\text { used for indexing OER: Dublin Core, SCORM, } \\
\text { LOM, free tags, etc. }\end{array}$ & \\
\hline
\end{tabular}

Category 2: Indicators of reuse. One of the benefits of ROER is that teachers have the opportunity to "reuse, modify, and adapt resources" (Hylén, Damme, Mulder, \& D’Antoni, 2012), and a secure and reusable platform is an important design factor that contributes to reuse (Wills \& Pegler, 2016). Hence, ROER that implement drivers contributing to reuse would become "beneficial reusable platforms" for users. Table 2 shows a proposal of facilitating factors, and gives reasons for this chosen focus. 
Table 2

\section{Indicators for Reuse}

\begin{tabular}{|c|c|c|c|}
\hline INDICATORS & DESCRIPTION \& VALUES & PURPOSE & REFERENCES \\
\hline Intentionality & $\begin{array}{l}\text { Specifications about the intertion to reuse: advice } \\
\text { about the suitability of the material, information } \\
\text { encouraging reuse, atc. } \\
\text { values } \mathrm{res} / \mathrm{No}_{\mathrm{O}}\end{array}$ & $\begin{array}{l}\text { A statement of intention } \\
\text { might reveal whether an } \\
\text { ROE supports reuse. }\end{array}$ & $\begin{array}{l}\text { in heuse indicator, since it has not been identified in } \\
\text { previbes studies. }\end{array}$ \\
\hline Versioning & $\begin{array}{l}\text { Technical sell tions provided to store different } \\
\text { versiors of the same resaurce. Therefore, reuse } \\
\text { occurs either by Lpdating material or making new } \\
\text { derivatives. } \\
\text { Value: Yes/No }\end{array}$ & $\begin{array}{l}\text { If the intenticn to reuse is } \\
\text { rather theoretical, offering } \\
\text { different versions is a more } \\
\text { practical selution. it inwolves } \\
\text { adapting an existing } \\
\text { resource. }\end{array}$ & $\begin{array}{l}\text { Repurposing tools that allow reusers to modify } \\
\text { material are one of the design drivers that support } \\
\text { different lewels of reuse (Wincle et ol., 2010). OER } \\
\text { resulting from an augmented version of the original } \\
\text { can contribute to improving the learning } \\
\text { environment (Maina \& Guardia, 2012). }\end{array}$ \\
\hline Licenses & $\begin{array}{l}\text { The main feature that allows the reuse and remix } \\
\text { of resources through the creation of derivative } \\
\text { works. } \\
\text { Value: Open licences / Hoth open \& restricted } \\
\text { (some collections are only avallable for the } \\
\text { community) /Restricted }\end{array}$ & $\begin{array}{l}\text { Specification of the type of } \\
\text { licence for each resource } \\
\text { should provide information } \\
\text { abeut the level of reuse. }\end{array}$ & $\begin{array}{l}\text { Open licenses are the main core feature for reuse } \\
\text { (Gesser, 2007) that differentiates OER from leaming } \\
\text { objects (Lane \& McAndrew, 2010). The more open a } \\
\text { license is, the more it facilitates the creation of } \\
\text { derivatives (Bissell, 2021), Only some CC licenses } \\
\text { allow reuse \{OECD, 2007; Fulantelli et of, 2008; } \\
\text { Jacabi \& van der Woert, 2012). }\end{array}$ \\
\hline Granularity & $\begin{array}{l}\text { This refers to the size of the resources that must } \\
\text { be decoupled from each other (like a Fussian doll): } \\
\text { single (modules, exercises, games, etc) or } \\
\text { multiples (sets or resources, courses, etc.) } \\
\text { Value: Yes/No }\end{array}$ & $\begin{array}{l}\text { This is diroctly connected to } \\
\text { reusability, because small, } \\
\text { granular, context neutral } \\
\text { resources are mora likely to } \\
\text { be reused in another } \\
\text { educational context, and are } \\
\text { more fiexible. }\end{array}$ & $\begin{array}{l}\text { Sichlia et at, 2010; Lttiejohn, 2003; Windle et al., } \\
\text { 2010, Yalcinalp \& Emiroglu, 2012. }\end{array}$ \\
\hline Open formats & $\begin{array}{l}\text { This is a file format with a freely available, } \\
\text { published specification, which allows open source } \\
\text { software tools for data reusers. } \\
\text { Values: Yes/No }\end{array}$ & $\begin{array}{l}\text { OER created with open } \\
\text { formats are more casily } \\
\text { reused, since they have more } \\
\text { technological optians and } \\
\text { are not limited to a } \\
\text { particular procuct/supplier. }\end{array}$ & $\begin{array}{l}\text { OER shoule be designed for easy reuse in open } \\
\text { content standards and formats (Gesser, 2007). Cne } \\
\text { key lasue for OEr polices is whish file formats should } \\
\text { be used to guarantee maximum factual cpenness } \\
\text { (Neumann } 8 \text { MuuB Merholz, 2016). }\end{array}$ \\
\hline $\begin{array}{l}\text { Quality } \\
\text { assurance }\end{array}$ & 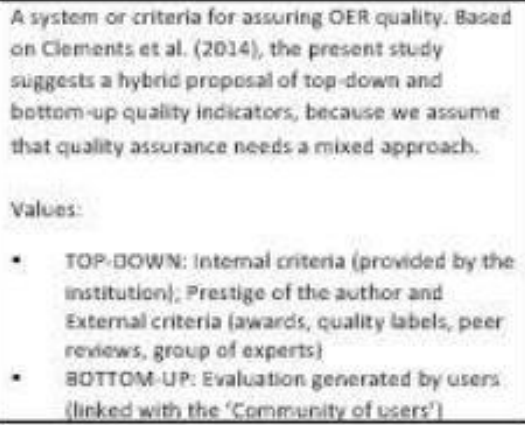 & $\begin{array}{l}\text { Qualty assurance is } \\
\text { considered a major driver of } \\
\text { reuse, since erily OERs of } \\
\text { sufficient cuatity gain a high } \\
\text { level of reuse. }\end{array}$ & 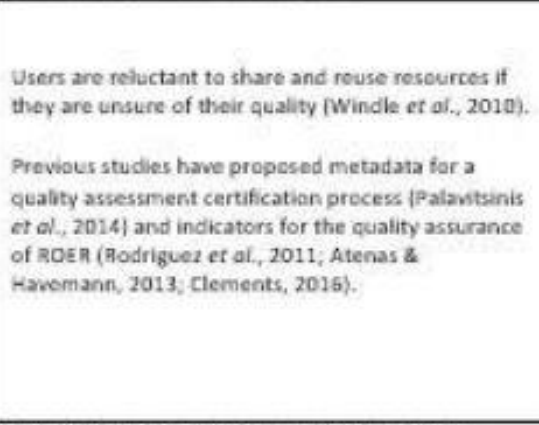 \\
\hline $\begin{array}{l}\text { Community } \\
\text { of users }\end{array}$ & $\begin{array}{l}\text { Contrbetion systems are available for the } \\
\text { community of users. They support user-generated } \\
\text { evaluation as a bottom-up quality sptem. } \\
\text { Values: } \\
\text { Sharing through social networks / Comments and } \\
\text { ratings }\end{array}$ & $\begin{array}{l}\text { Since reuse requires a level } \\
\text { of trust between creators } \\
\text { and reusers (Pogler, 2011) } \\
\text { and those whe are already } \\
\text { involved with reuse help in } \\
\text { is implementation (wils, } \\
20131 \text {, a community of users } \\
\text { of ROer should drive reuse. }\end{array}$ & 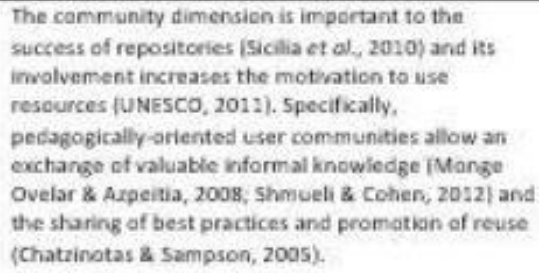 \\
\hline
\end{tabular}


Category 3: Educational indicators. Since it has been emphasized that the pedagogical value of educational resources is the most important factor (McGreal, 2004), Table 3 proposes a series of indicators that are designed to describe ROER from an educational perspective.

Table 3

\section{Educational Indicators}

\begin{tabular}{|c|c|c|c|}
\hline INDICATORS & DESCRIPTION & VALUES & REASONING \& REFERENCES \\
\hline OER type & $\begin{array}{l}\text { Information about the types of OER, } \\
\text { identified through specific metadata, } \\
\text { filters or limiters that allow searches } \\
\text { for types of resources. }\end{array}$ & Yes/No & \\
\hline \multirow{8}{*}{$\begin{array}{l}\text { Educational } \\
\text { metadata }\end{array}$} & \multirow{8}{*}{$\begin{array}{l}\text { Specific metadata for educational } \\
\text { aspects are provided. }\end{array}$} & Educational level/grade & \multirow{8}{*}{$\begin{array}{l}\text { Educational metadata can be used to } \\
\text { assess the educational relevance of } \\
\text { ROER (Rodriguez et al., 2011; Atenas } \\
\text { \& Havemann, 2011). However, } \\
\text { because of the imprecision and poor } \\
\text { quality of metadata records, the } \\
\text { content is not fully validated } \\
\text { (Palavitsinis, Manouselis \& Sanchez- } \\
\text { Alonso 2014). }\end{array}$} \\
\hline & & Educational context & \\
\hline & & Intended/suggested use & \\
\hline & & Learning time & \\
\hline & & Intended audience & \\
\hline & & Pedagogy & \\
\hline & & Syllabus/curriculum & \\
\hline & & No specific metadata for education & \\
\hline Learning goals & $\begin{array}{l}\text { Specific metadata for learning goals } \\
\text { are provided. }\end{array}$ & Yes/No & $\begin{array}{l}\text { Supported by the users' need in ROER } \\
\text { for "detailed information related to } \\
\text { each OER and objectives for using } \\
\text { them must be given" (Yalcinalp \& } \\
\text { Emiroglu, 2012). }\end{array}$ \\
\hline
\end{tabular}

\section{Data Gathering and Analysis}

Content analysis was carried out for each of the 110 repository websites, using Tables 1 to 3 as codification frameworks. Tools for retrieving information from each website were used, such as searching (filters and metadata) and browsing (documentation). Data were collected between 2015 and 2016.

Content analysis limitations were broken URLs, duplicate data and the omission of pertinent data. Another limitation of this study was that some repositories are available in other languages, and have not been translated into English.

\section{Results and Discussion}

This section presents and discusses data from the analysis of ROER websites. In addition, some relevant ROER are highlighted as models of good practices.

\section{ROER Types and Technology}


Main features. Table 4 indicates that there are more OER repositories that only contain learning resources (54.5\%) than hybrid repositories (45.5\%) containing research and learning resources.

Table 4

OER Stored Wholly or Partially

\begin{tabular}{|l|c|c|}
\hline \multicolumn{1}{|c|}{ Typology } & Total & $\%$ \\
\hline Hybrid repositories & 50 & $45.5 \%$ \\
\hline Exclusively OER repositories & 60 & $54.5 \%$ \\
\hline
\end{tabular}

Most ROER (Tables 5 and 6) were multidisciplinary (73.6\%). The second most common discipline in ROER was Science, Technology, Engineering, and Maths (STEM, 12.7\%). Most ROER were dedicated to higher education (85.5\%); a lower number covered different levels of education (14.5\%). Although a multidisciplinary approach also seemed more common in a previous analysis (OECD, 2007), other data suggest that single-subject repositories would be more suitable for teachers, since it is harder for teachers to find and use relevant OER for their subjects in broader repositories (Sampson, Zervas, \& Sotiriou, 2013).

Table 5

Disciplines

\begin{tabular}{|l|c|c|}
\hline \multicolumn{1}{|c|}{ Disciplines (HEA Academy) } & Total ROER & $\%$ \\
\hline Multidisciplinary & 81 & $73.6 \%$ \\
\hline $\begin{array}{l}\text { STEM - Science, Technology, } \\
\text { Engineering and Mathematics }\end{array}$ & 14 & $12.7 \%$ \\
\hline Social Science & 10 & $9 \%$ \\
\hline Arts \& Humanities & 3 & $2.7 \%$ \\
\hline Health \& Social Care & 2 & $1.8 \%$ \\
\hline
\end{tabular}

Table 6

Educational Level

\begin{tabular}{|l|c|c|}
\hline \multicolumn{1}{|c|}{ Typology } & Total & $\%$ \\
\hline Higher education & 94 & $85.5 \%$ \\
\hline All levels of education & 16 & $14.5 \%$ \\
\hline
\end{tabular}


Authorship. It was found that the prevailing ROER were institutional $(76.4 \%$ created by universities, foundations or institutes) and the rest were national (23.6\% funded by governments, national organizations or consortia). This pattern is similar to that found in another analysis (Atenas \& Havemann, 2013), in which institutional ROER were also predominant, but to a lesser extent (50\% of the total, while the rest was broken down into different types).

Geographical origin. As stated in the literature (Tzikopoulos et al., 2007; Atenas \& Havemann, 2013), most ROER were created in Europe (72.7\%) and North America (16.3\%) (see Table 7). Others were scattered between South America (6.3\%), Asia (3.6\%) and Africa (0.9\%). Twenty-seven countries were represented in the total ROER population (Table 8). The countries that created the highest numbers of ROER were the UK (18.1\%), Spain (15.4\%), the USA (13.6\%) and France (10\%).

The success of ROER in the UK might be due to the considerable funding provided for OER projects by the Joint Information Systems Committee (JISC). This pattern varies in other studies (Bueno-de-laFuente et al., 2009), in which the USA was found to be the most common location (28\%), followed by Germany and Italy. However, our results might be influenced by the fact that they only focus on higher education ROER. The countries that were found to be most involved in ROER may coincide with the countries in which most publications about OER have been identified (Zancanaro et al., 2015).

Table 7

Geographical Origin of ROER (Continents)

\begin{tabular}{|l|c|c|}
\hline Continents & Total & $\%$ \\
\hline Europe & 80 & $72.7 \%$ \\
\hline Asia & 4 & $3.6 \%$ \\
\hline North America & 18 & $16.3 \%$ \\
\hline Africa & 1 & $0.9 \%$ \\
\hline South America & 7 & $6.3 \%$ \\
\hline
\end{tabular}


Table 8

Geographical Origin of ROER(Countries)

\begin{tabular}{|c|c|c|}
\hline Countries & $\begin{array}{l}\text { Total } \\
\text { ROER }\end{array}$ & $\%$ \\
\hline UK & 20 & 18.2 \\
\hline Spain & 17 & 15.5 \\
\hline US & 15 & 13.6 \\
\hline France & 11 & 10 \\
\hline Germany & 9 & 8.2 \\
\hline Colombia & \multirow[t]{2}{*}{4} & \multirow{2}{*}{3.6} \\
\hline Poland & & \\
\hline Brazil & \multirow{3}{*}{3} & \multirow{3}{*}{2.7} \\
\hline Greece & & \\
\hline Ukraine & & \\
\hline Mexico & \multirow{4}{*}{2} & \multirow{4}{*}{1.8} \\
\hline Portugal & & \\
\hline Belarus & & \\
\hline Indonesia & & \\
\hline Canada & \multirow{13}{*}{1} & \multirow{13}{*}{0.9} \\
\hline China & & \\
\hline Estonia & & \\
\hline Finland & & \\
\hline Kenya & & \\
\hline Belgium & & \\
\hline India & & \\
\hline Ireland & & \\
\hline Italy & & \\
\hline Slovenia & & \\
\hline Russian Federation & & \\
\hline Sweden & & \\
\hline Switzerland & & \\
\hline 27 & 110 & $100 \%$ \\
\hline
\end{tabular}

Software platform. Data on the technology that supports ROERs platforms (Table 9) suggests that DSpace is the most popular software (34.5\%), followed by a range of other software (19.1\%), some content management systems (CMS) and learning management systems (LMS) (11.8\%), and Eprints (7.3\%). Other software that is used to a lesser extent is dLibra, Equella, Fedora, and MyCore. However, in a significant number of ROERs (14.5\%), the platform was not identified, as it was not mentioned in their policies or anywhere else. This result coincides with that of OpenDOAR and Bueno-de-la-Fuente (2009), although recent studies (Amiel \& Soares, 2016) have indicated a tendency to adopt CMS in the ROER scene. 
Table 9

Software Platform

\begin{tabular}{|l|c|r|}
\hline \multicolumn{1}{|c|}{ Repository software } & Total & \multicolumn{1}{c|}{$\%$} \\
\hline Dspace & 38 & $34.5 \%$ \\
\hline $\begin{array}{l}\text { Others (NClor, Hydra, OMEKA, } \\
\text { Run CoCo, Miless, DiDoRe, etc.) }\end{array}$ & 21 & $19.1 \%$ \\
\hline Not identified & 16 & $14.5 \%$ \\
\hline Web/CMS/LMS & 13 & $11.8 \%$ \\
\hline Eprints & 8 & $7.3 \%$ \\
\hline dLibra & 4 & $3.6 \%$ \\
\hline Fedora & 4 & $3.6 \%$ \\
\hline EQUELLA & 3 & $2.7 \%$ \\
\hline MyCoRe & 2 & $1.8 \%$ \\
\hline
\end{tabular}

Metadata standards. The indexing of resources using metadata facilitates their location, dissemination and harvesting from other online platforms. In this analysis, the most widely used metadata standard in ROER was Dublin Core (DC, 50.9\%). It was not specified whether simple or qualified DC was used, but both types may be involved, since additional qualifiers that further refine the meaning of OER have been found. The predominance of the DC element set might be due to the fact that DSpace uses it as its base metadata schema and DSpace was the most popular software used in ROER, as shown above.

However, the DC schema cannot efficiently characterize educational material or meet the needs of ROER (Koutsomitropoulos, Alexopoulos, Solomou, \& Papatheodorou, 2010). Accordingly, several educational metadata standards have appeared over time, to improve the description of educational resources by identifying their pedagogical properties. A widely adopted standard is IEEE LOM (Learning Object Metadata), which has an inherent extension capability (Al-Khalifa and Davis, 2006) and attributes that enable learning resources to be managed and evaluated (Nair \& Jeevan, 2004). Other learning specifications are IMS, which is a development of LOM, and SCORM (Sharable Content Object Reference Model) for sequencing structured educational material in the form of reusable content. 
Table 10

\section{Metadata Standards}

\begin{tabular}{|l|c|c|}
\hline \multicolumn{1}{|c|}{ Metadata standard } & Total & $\%$ \\
\hline Dublin Core & 56 & 50.9 \\
\hline Not identified & 19 & 17.3 \\
\hline LOM/SupLOMFR & 16 & 14.5 \\
\hline Free Tags & 10 & 9.1 \\
\hline Other & 4 & 3.6 \\
\hline METS/PLMET & 3 & 2.7 \\
\hline SCORM & 1 & 0.9 \\
\hline IMS QTI & 1 & 0.9 \\
\hline TOTAL & 110 & \\
\hline
\end{tabular}

Twenty per cent of the ROER adopted specific educational medatada standards for describing the OER (table 11). The most commonly used standards were LOM/SupLOMFR (14.5\%), SCORM (0.91\%), IMS (0.91\%) and others (3.6\%) (see Tables 10 and 11). Some other ROER provided a free tag system (9.1\%). Lastly, 2.7\% used a generic schema for describing digital objects, called METS/PLMET.

Table 11

Educational Metadata Standard

\begin{tabular}{|l|c|}
\hline \multicolumn{1}{|c|}{$\begin{array}{c}\text { Educational metadata } \\
\text { standard }\end{array}$} & Total \\
\hline LOM/SupLOMFR & 16 \\
\hline SCORM & 1 \\
\hline IMS QTI & 1 \\
\hline Other educational standard & 4 \\
\hline TOTAL & $22(=20 \%)$ \\
\hline
\end{tabular}

The pattern shown by these data contrasts with the findings of other studies, in which the importance of IEE LOM (29\% of ROER) outstripped that of DC (22\%) (Tzikopoulos et al., 2007) and in which less volume and fewer details of the metadata standard (37.7\% included either DC or LOM) were identified (Atenas \& Havemann, 2013).

\section{Reuse in ROER}

Intentionality. A total of $36.3 \%$ of ROER expressed an intention to reuse materials, in the form of 
- comments in the mission or in the collection's policies, which were found in ARIADNE, the University of Leicester's OER Repository or Xpert, for example;

- advice and instructions on the reuse of resources. Open Michigan has a "Use Open Content" section, with recommendations on how to adapt and license resources; and

- messages encouraging users to remix resources. NCLOR proposes that teachers can become more productive and save valuable time if they contribute new versions of resources. OER Africa also encourages teachers to adapt materials to African contexts and learners.

Table 12

Intention to Reuse

\begin{tabular}{|l|c|c|}
\hline Intention to reuse & Total & $\%$ \\
\hline Yes & 40 & $36.3 \%$ \\
\hline No & 70 & $63.6 \%$ \\
\hline TOTAL & 110 & \\
\hline
\end{tabular}

Versioning. Thirteen of the ROER used some technical implementations to record different versions of the same resource. For instance, Jorum allows "multiple versions of an object to be deposited by adding information on the version in the description." Other ROER provided the following.

- Search filters to retrieve available versions, including information on where a specific resource was used (RADAR), how to reuse resources (HUMBOX), and where to find resources to remix or make derivatives (OER Commons).

- Specific metadata and sections for versioned resources, including "Life cycle" or "Details" (CURVE, Dashboard Equella and Banco de Objetos Virtuales de Aprendizaje), "Version History" (OpenStax CNX) and "Copy history based" (TEMOA).

- The most developed ROER showed chronologically who, when, and which files had been changed (DuEPublico); offered assistance about how to reuse or create contents that are suitable for reuse (in TEMOA "you can mix and match other people's items to build new ones and adapt them to your needs") and recommended how to reuse and attribute educational content (OpenStax CNX).

Of the subtotal of ROER that described reuse intentions (40 out of 110 repositories) (Table 13), only 32.5\% (13 out of 40 ROER) included versioning. Therefore, a more intentional rather than a technical solution to support reuse has been observed. This may be because maintenance and updating are problems that ROER are struggling with (McGreal, 2011). 
Table 13

Versioning

\begin{tabular}{|l|c|c|}
\hline \multicolumn{1}{|c|}{ Repositories with REUSE } & Total & $\%$ \\
\hline Intentionally & 27 & $67.5 \%$ \\
\hline Through versioning & 7 & $17.5 \%$ \\
\hline Intentionally \& through versioning & 6 & $15 \%$ \\
\hline TOTAL & 40 & \\
\hline
\end{tabular}

Licenses. Table 14 shows that only $5.5 \%$ of repositories had restricted access to resources (copyright with all rights reserved or login requirements). A total of $56.4 \%$ had an open license, 24.5 had both open and restricted licenses and, finally, $13.6 \%$ did not specify the license.

Amongst the open licenses, Creative Commons (CC) prevailed (43.6\%), followed by specific licenses for educational use (10\%), and other in-house licenses provided by the repositories (2.7\%). As for ROER with a combination of both open and restricted access, 11 out of 27 were found to have CC.

Table 14

Licenses

\begin{tabular}{|l|l|c|c|}
\hline License access & \multicolumn{1}{|c|}{ License type } & ROER & $\%$ \\
\hline \multirow{4}{*}{ Open } & $\mathrm{CC}$ & 48 & 43.6 \\
\cline { 2 - 4 } & For educational use & 11 & 10 \\
\cline { 2 - 4 } & In-house license & 3 & 2.7 \\
\cline { 2 - 4 } & Subtotal Open & $\mathbf{6 2}$ & $\mathbf{5 6 . 4}$ \\
\hline \multirow{2}{*}{$\begin{array}{l}\text { Both open \& } \\
\text { restricted }\end{array}$} & Not identified & 16 & 14.5 \\
\cline { 2 - 4 } & CC & 11 & 10 \\
\cline { 2 - 4 } & Subtotal Open \& Restricted & $\mathbf{2 7}$ & $\mathbf{2 4 . 5}$ \\
\hline \multicolumn{2}{|l|}{} & $\mathbf{6}$ & $\mathbf{5 . 5}$ \\
\hline & Restricted & $\mathbf{1 5}$ & $\mathbf{1 3 . 6}$ \\
\hline & Unspecified & 110 & \\
\hline
\end{tabular}

In some studies, $76 \%$ of ROER had copyright policies (Tzikopoulos et al., 2007) and 52.5\% (Atenas \& Havemann, 2013) or 22\% (Amiel \& Soares, 2016) had CC licenses. Our results were more positive, since they showed an increase in openness of ROER and in the use of CC. However, there were still very few $\mathrm{CC}$ licenses, considering that they are relatively easy to adopt and lead to greater access, use and reuse of resources.

Our findings also revealed that $\mathrm{CC}$ are more commonly implemented in the USA and Europe, where 
more ROER are based. The opposite situation was found by Atenas \& Havemann (2013), where the incidence of CC was greater in areas with fewer ROER (in Oceania, the Middle East and Africa).

The specific type of $\mathrm{CC}$ license provided by ROER can reveal the real opportunities they provide to reuse resources. Out of a total of 59 ROER with CC (Table 14), we observed (Table 15) that most allowed reuse (86.4\%): 42.4\% were Attribution-Noncommercial-Share Alike (BY-NC-SA), 27.1\% used any of the six CC licenses, and $16.9 \%$ were under BY-NC. This last license allows others to non-commercially remix the original work, and, if it is also combined with SA (BY-NC-SA), new creations that build on the original work must be licensed under identical terms. The remaining $13.6 \%$ that did not allow any reuse corresponded to the most restrictive CC (BY-NC-ND), which only permits others to download and share resources if they credit the author, and does not allow the material to be changed in any way or used commercially.

Table 15

\section{Creative Commons Licenses}

\begin{tabular}{|l|c|c|c|}
\hline \multirow{4}{*}{ CC that allow reuse } & CC license & Number & $\begin{array}{c}\text { \% of ROER } \\
\text { with CC (59) }\end{array}$ \\
\cline { 2 - 4 } & BY-NC-SA & 25 & 42.4 \\
\cline { 2 - 4 } & Any of the 6 CC licenses & 16 & 27.1 \\
\cline { 2 - 4 } & BY-NC & 10 & 16.9 \\
\cline { 2 - 4 } & Subtotal allowing reuse & $\mathbf{5 1}$ & $\mathbf{8 6 . 4}$ \\
\hline \multirow{2}{*}{$\begin{array}{l}\text { CC that do not allow } \\
\text { reuse }\end{array}$} & BY-NC-ND & 8 & 13.6 \\
\cline { 2 - 4 } & Subtotal not allowing reuse & $\mathbf{8}$ & $\mathbf{1 3 . 6}$ \\
\hline & Total CC & 59 & \\
\hline
\end{tabular}

The preponderance of the CC-BY-NC-SA license is in line with the findings of other studies (Venturini, 2014; Amiel \& Soares, 2016), but was clearly higher in the current research (42.4\% versus $8 \%$ found by Amiel).

Although the number of $\mathrm{CC}$ licenses that facilitated reuse was high (51 out of 59), it still only represented less than half of the total ROER ( 51 out of 110 ).

Granularity. It was found (Table 16) that just 20.9\% of ROER had resources with different levels of granularity. Other research has shown that granular resources are more valued and effective for users (Wharrad \& Windle, 2010) and play an important role in reuse for teaching and learning (Yalcinalp \& Emiroglu, 2012).

Learning Space specifies that resources can be catalogued both as single entities (an entire manual) and constituent parts (chapters). Temoa also refers to resources as topics, activities or courses. ATE Central provides separate categories for "'instructional unit" and "courses;" RUA provides specific metadata (c.relation.ispartof) to indicate that modules are part of a subject or course, and RADAR links the different units related to a course. 
Table 16

Granularity

\begin{tabular}{|l|c|c|}
\hline \multicolumn{1}{|c|}{ Typology } & Total & $\%$ \\
\hline Higher education & 94 & $85.5 \%$ \\
\hline All levels of education & 16 & $14.5 \%$ \\
\hline
\end{tabular}

Granularity and the rest of the indicators of reuse (Table 17) were found to be interconnected. Thus, ROER with granularity also included social networks (78.3\%), a quality system (73.9\%) and some intention for reuse or versioning (60.9\%).

Table 17

Indicators of Reuse in ROER with Granularity

\begin{tabular}{|l|c|c|}
\hline ROER with granularity (23) and: & Number & $\%$ \\
\hline Social networks & 18 & 78.3 \\
\hline Quality system & 17 & 73.9 \\
\hline Reuse intentional/versioning & 14 & 60.9 \\
\hline Comments or ratings & 13 & 56.5 \\
\hline CC for reuse & 11 & 47.8 \\
\hline Open formats & 2 & 8.7 \\
\hline
\end{tabular}

Open formats. A total of $15.4 \%$ of the ROER included open formats (Table 18). Amongst these, only $9.1 \%$ implemented open formats as metadata; the other $6.3 \%$ included open formats, but they did not appear in the results.

Table 18

Open Formats

\begin{tabular}{|l|c|c|}
\hline \multicolumn{1}{|c|}{ Open formats } & Total & $\%$ \\
\hline Not included in metadata & 93 & $84.5 \%$ \\
\hline Included in metadata & 10 & $9.1 \%$ \\
\hline Open formats amongst results & 7 & $6.3 \%$ \\
\hline
\end{tabular}

Ten of the 17 ROER with open formats also supported reuse (intentionally or through versioning), and 14 had open licenses (most of them were CC; some had licenses for educational use). These results are fairly consistent if we consider that open formats should facilitate reuse. 
Some good practices regarding open formats in ROER were the inclusion of recommendations about their adoption, which were found in some guidelines: "attention should be given to the adoption of open standards. We would generally recommend resource authors to use open source solutions in preference to proprietary ones" (ReStore); "open formats ensure the preservation of resources" (Eprints UCM) and "whenever is possible, the open and easily re-usable formats should be used" (Oregon's repository). Finally, MERLOT is committed to creating materials with Content Builder and Pachyderm open software.

Some preferred formats that were detected are: .odt or .txt for text and .flac for audio (Oregon's repository), epub for ebooks (Open Learn), html/xml (DLynx, UVED, OpenStax CNX and UOH) and Css for web (Jorum).

Quality. A total of $43.6 \%$ of the ROER specifically mentioned quality, from a top-down perspective and according to three types of criteria (Table 19). This result contrasts with that of other studies (Castaño et al., 2016), in which quality assurance was even less present (11\%).

Table 19

Top-Down Quality Criteria

\begin{tabular}{|c|c|c|c|c|}
\hline \multicolumn{2}{|c|}{ Top-down quality indicators } & Detail & Total & $\%$ \\
\hline \multirow{7}{*}{ WITH CRITERIA } & Internal criteria & Provided by the institution & 22 & 20 \\
\hline & Author prestige & Provided by the authors themselves & 15 & 13.6 \\
\hline & \multirow{4}{*}{ External criteria } & Peer review & 8 & 7.3 \\
\hline & & Group of experts & 2 & 1.8 \\
\hline & & Award or Quality labels & 2 & 1.8 \\
\hline & & Subtotal & 11 & 10 \\
\hline & \multicolumn{2}{|c|}{ Subtotal of top-down criteria } & 48 & 43.6 \\
\hline \multirow{4}{*}{ WITHOUT CRITERIA } & No criteria & & 4 & 3.6 \\
\hline & Unspecified & & 58 & 52.7 \\
\hline & \multicolumn{2}{|c|}{ Subtotal of no criteria } & 62 & 56.4 \\
\hline & TOTAL & & 110 & \\
\hline
\end{tabular}

According to our data, the most common approach when there is a form of quality assurance is internal assessment (20\%), followed by the prestige of authors (13.6\%) and external reviews (10\%). This pattern is aligned with UNESCO (2011), which states that institutions are responsible for assuring the quality of OER used in teaching and learning environments, and should invest in improving quality before making materials available in ROER. The peer review, which is used extensively in scholarly publishing, has also become a quality assurance measure in ROER (Clements et al., 2015).

Institutions often ensure quality through the OER submission process (publishing rules) rather than the content. However, quality parameters exist in some cases, for example in the JISC Enriching Digital Resources Programme (in the First World War Poetry Digital Archive). Other ROER use guidelines that guarantee relevant OER: those with "learning objectives, instructional strategies and alignment 
with educational standards" (Exploratorium's Howtosmile), and with "an eminent educational or research purposes in teaching" (Open $S N H$ ). In other cases, a review checklist is provided before resources are uploaded (Humbox).

The main reasons given by ROER that provide quality through recognition of the author are that the authenticity of the content is the sole responsibility of the creator, and authors have been full-time lecturers for other organizations and are experts in their fields. With these arguments, ROER exempt themselves from any responsibility for content, as authors must meet certain conditions before submitting OER (Temoa) or must participate in all the development stages (Chem Collective).

Some ROER based on peer review systems rely on specialist groups (Learning Exchange) or editorial boards (Merlot) that decide which resources are suitable for their communities. Others make public their review criteria, such as "content quality, scope, beneficiaries, usability and potential ongoing value of the site" (Restore) and "high scientific accuracy, good pedagogical effectiveness, ease of use, clarity and completeness of documentation, motivating for learners, show robustness, and illustrate significance of content" (DLESE).

The few ROERs (3.6\%) that do not explicitly assume liability for their resources (Table 19) are those stored in external containers (such as WLP), or not subject to quality control (DuEPublico).

A bottom-up quality approach based on user-generated evaluation (by rating and comments) will be analyzed in the next section.

Community of users. A total of $62.7 \%$ of ROER (69 out of 110) provided some kind of community engagement (in the remaining cases, this was an unknown factor). The most common interaction allowed was recommending OER by sharing them through social networks, electronic mail or RSS. This was found in approximately half of the ROER (54 out of 110). Conversely, less than onequarter of ROER allowed comments (19 out of 110) or ratings (12 out of 110). Thus, in terms of ensuring a bottom-up quality system based on user action, ROER took less account of evaluation tools, such as rating, than of social media services.

Table 20

Community of Users (Bottom-Up Quality Criteria)

\begin{tabular}{|l|l|c|c|}
\hline Bottom-up quality criteria & $\begin{array}{l}\text { Type of Community } \\
\text { engagement }\end{array}$ & Total & $\%$ \\
\hline \multirow{4}{*}{ Social interaction } & Sharing & 54 & 49.1 \\
\cline { 2 - 4 } & Comments & 10 & 9.1 \\
\cline { 2 - 5 } & Comments \& ratings & 5 & 4.5 \\
\cline { 2 - 5 } & Total social interaction & $\mathbf{6 9}$ & $\mathbf{6 2 . 7}$ \\
\hline Unspecified & Unspecified & $\mathbf{4 1}$ & $\mathbf{3 7 . 3}$ \\
\hline & TOTAL & 110 & \\
\hline
\end{tabular}

These findings are similar to some previous results (Atenas \& Haveman, 2013), in which 51.2\% of ROER 
allowed sharing, and $32.5 \%$ allowed ratings. However, it is difficult to discern what these numerical scores mean: are they positive enough to claim real community engagement or do they demonstrate the existence of review systems for users? Some authors (Zervas et al., 2014) found that social functionalities were not strong enough to assure quality (Ochoa \& Duval, 2009). Clement (2016) added that they were insufficient if unsupported by a users' community. At the moment, these results show the extent to which community systems are available in ROER.

In a more qualitative analysis, some examples of ROER point to the existence of community spaces and behaviours. These include: discussion areas and special interest groups (in Promethean Planet); groups of contributors that use and comment on OER (in Humboldt Digital Scholar and LORO); communities of interest and disciplines with their own YouTube channel and blogs for registered users (in MERLOT); and international communities involved in creating and adapting OER and participating in a blog and wiki (in Open Michigan). Other ROER have recognition systems to evaluate and receive recognition from the community. For example, some assess members' level of contribution (TEMOA) or provide "top members" ratings (Promethean Planet).

Finally, a comparison of all the proposed indicators of reuse (Table 21) shows that while they do not have enough presence in ROER (all figures were below 50\%), except licensing and social networks (close to or over 50\%), most have a greater incidence in OER-exclusive repositories. In these, the features that were found most frequently were again licensing and social networks (with an increment of 20.9 points), as well as quality, intention and versioning. Note that although the figure for granularity is still low (38.3\%), it is much higher than in the total ROER (17.4 points higher).

Table 21

Indicators of Reuse

\begin{tabular}{|l|l|c|c|c|c|c|}
\hline \multicolumn{2}{|c|}{ INDICATORS OF REUSE } & \multicolumn{2}{|c|}{$\begin{array}{c}\text { Total ROER } \\
\text { Number }\end{array}$} & \multicolumn{2}{c|}{$\begin{array}{c}\text { Total OER-exclusive } \\
\text { repositories } \\
\text { Number }\end{array}$} & $\begin{array}{c}\text { \% Difference (OER- } \\
\text { exclusive vs. total ROER) }\end{array}$ \\
\hline $\begin{array}{l}\text { Total intention } \\
\text { \& versioning }\end{array}$ & & 40 & 36.4 & $\mathbf{3 2}$ & $\mathbf{5 3 . 3}$ & $\mathbf{1 7}$ \\
\hline \multirow{2}{*}{ Licensing } & $\begin{array}{l}\text { Open } \\
\text { licenses }\end{array}$ & 62 & 56.4 & 37 & 61.7 & 5.3 \\
\cline { 2 - 8 } & CC licenses & $\mathbf{5 9}$ & $\mathbf{5 3 . 6}$ & $\mathbf{3 8}$ & $\mathbf{6 3 . 3}$ & 9.7 \\
\hline Granularity & & 23 & 20.9 & 23 & 38.3 & $\mathbf{1 7 . 4}$ \\
\hline Open formats & & 10 & 9.1 & 6 & 10 & 0.9 \\
\hline Quality & & 48 & 43.6 & $\mathbf{3 3}$ & $\mathbf{5 5}$ & 11.4 \\
\hline \multirow{2}{*}{$\begin{array}{l}\text { Community of } \\
\text { users }\end{array}$} & $\begin{array}{l}\text { Social } \\
\text { networks }\end{array}$ & $\mathbf{5 4}$ & $\mathbf{4 9 . 1}$ & $\mathbf{4 2}$ & $\mathbf{7 0}$ & $\mathbf{2 0 . 9}$ \\
\cline { 2 - 8 } & $\begin{array}{l}\text { Comments } \\
\text { or ratings }\end{array}$ & 31 & 28.2 & 24 & 40 & 11.8 \\
\hline
\end{tabular}

\section{Educational Aspects}

OER types. The ROER ( $85.4 \%$ ) provided information about the type of stored resources (Table 22). This information was usually found in the metadata "dc.format" or "dc.format.mimetype," other 
related metadata, or the search type drop-down list.

Table 22

Metadata on Type of Resources

\begin{tabular}{|c|c|c|}
\hline Type of resource & Total & $\%$ \\
\hline Yes & 94 & $85.4 \%$ \\
\hline No & 16 & $14.5 \%$ \\
\hline
\end{tabular}

Table 23 shows the wide range of resources that were identified in the ROER.

Table 23

Types of OERS

\begin{tabular}{|l|l|l|}
\hline \multirow{4}{*}{ Media Type } & Text & $\begin{array}{l}\text { Textbooks, book chapters, exercises, courses, modules, lessons, } \\
\text { weblinks, webgraphies, blogs and wikis. }\end{array}$ \\
\cline { 2 - 3 } & Image & illustrations, graphics, maps and photographs \\
\cline { 2 - 3 } & Audio-visual & Videos, interactive multimedia and podcast. \\
\cline { 2 - 3 } & Interactive material & Animations, games, self-evaluation, digital media and experiments. \\
\cline { 2 - 3 } & Software & Simulators, demos or other tools and desktop applications. \\
\hline \multirow{4}{*}{ Educational Type } & Guides & Guides, syllabus, glossaries, indexes and reference lists. \\
\cline { 2 - 3 } & Course material & $\begin{array}{l}\text { Course lectures, case studies, presentation, notes, datasets, } \\
\text { conferences and slides. }\end{array}$ \\
\cline { 2 - 3 } & Assessment material & $\begin{array}{l}\text { activities, essays, assignments, quizzes, tests, exams, thesis, and } \\
\text { final degree assessments }\end{array}$ \\
\cline { 2 - 3 } & Methods & Teaching presentations, slides, etc. \\
\hline
\end{tabular}

The content policies of the ROER tended to state what kind or resources could be included in the collections and who could include material. For instance, RODERIC asserted that "by teaching documents we mean any original material that may be of interest for use in the classroom" and LEEDSMET added that resources "may only be deposited by accredited members of the institution or their delegated agents". In addition, Open Access policies establish that doctoral theses, final degree projects and dissertations must be deposited (PADEMOS and RIUMA) and, in some cases educational resources must also be deposited (UCREA).

Some ROER provided resources specifically about teaching and innovation in teaching as disciplines (DUGI Docs) or offered specific collections on Curricula and Pedagogy (Belarusian National). Finally, PADEMOS provided a collection of "Material accessible to people with disabilities."

Educational metadata. A total of $42.7 \%$ of the ROER included specific metadata related to education (Table 24). The most popular educational metadata were "educational level or grade" (14.5\%) and "intended or suggested use" (10.9\%). Others were related to the intended audience, pedagogy, knowledge area, learning goals, learning time and related syllabus. Finally, in some cases in which there were no specific metadata for educational aspects, other information about targeted users or educational intention was located in fields designed for descriptions or comments. 
Table 24

Types of Educational Metadata

\begin{tabular}{|l|c|c|}
\hline \multicolumn{1}{|c|}{ Type of educational metadata } & Total & \% \\
\hline Educational level/grade & 16 & 14.5 \\
\hline Intended/suggested use & 12 & 10.9 \\
\hline Intended audience & 6 & 5.4 \\
\hline Pedagogy & 3 & 2.7 \\
\hline Education subdiscipline/knowledge area & 3 & 2.7 \\
\hline Learning goal & 3 & 2.7 \\
\hline Learning time & 2 & 1.8 \\
\hline Syllabus & 2 & 0.8 \\
\hline Total specific for education & $\mathbf{4 7}$ & $\mathbf{4 2 . 7}$ \\
\hline Nonspecific for education & $\mathbf{6 3}$ & $\mathbf{5 7 . 3}$ \\
\hline
\end{tabular}

Regarding the type of standards used by ROER with and without educational metadata (Table 25), most of the ROER that used DC did not include specific educational metadata. In contrast, the vast majority of ROER that used educational metadata standards based on LOM or SCORM (19 out of 22) also provided metadata on specific educational aspects. This pattern could be seen as a logical consequence of the inherent characteristics of each metadata standard. Therefore, a greater presence of educational standards is expected in ROER that provide educational data, since these standards have been created with this purpose.

Table 25

Educational Standards and Metadata in ROER

\begin{tabular}{|c|c|c|c|c|c|c|c|}
\hline ROER & DC & $\begin{array}{c}\text { Educational Standard } \\
\text { (LOM, SCORM \& IMS) }\end{array}$ & $\begin{array}{c}\text { Free } \\
\text { tags }\end{array}$ & METS & $\begin{array}{c}\text { Not } \\
\text { identified }\end{array}$ & Total & $\%$ \\
\hline With educational metadata & 18 & 18 & 5 & 3 & 3 & $\mathbf{4 7}$ & $\mathbf{4 2 . 7}$ \\
\hline Without educational metadata & 38 & 4 & 5 & & 16 & $\mathbf{6 3}$ & $\mathbf{5 7 . 3}$ \\
\hline Total & $\mathbf{5 6}$ & $\mathbf{2 2}$ & $\mathbf{1 0}$ & $\mathbf{3}$ & $\mathbf{1 9}$ & $\mathbf{1 1 0}$ & \\
\hline
\end{tabular}

The results also showed another striking case: ROER with educational metadata using specific educational standards were equal in number to those using DC (18 in each case). This parity might be due to the possibility of mixing different metadata standards in the same repository, which is known as crosswalks metadata. This creates compatibility between descriptions, builds rich contexts for learning, and is useful for unnamed information that needs to be integrated (Godby, Young, \& Childress, 2004). For instance, LOM elements can be incorporated in the default DSpace's qualified DC schema by direct mapping or by creating a further implementation (Koutsomitropoulos et al., 2010; Alexopoulos, Solomou, Koutsomitropoulos, \& Papatheodorou, 2010; Skourlas et al., 2016). Therefore, DC metadata can be extended and optimized for education by incorporating educational descriptors. Some examples of metadata co-existing on the same platform can be seen in Jorum, which combines DC 
(dc.audience), LOM (lom.educational.context) and JMD packages (jmd.oer) in the same register, and ARES UNASUS, which has its own metadata system based on LOM (f.i, unasus.typicalLearningTime).

Learning goals. Just $29.1 \%$ of ROER included learning goals (Table 26). They were most commonly located in a description field (40.6\%), but they were also found in specific descriptors for "Learning objectives" (37.5\%) and "Instruction method/pedagogy" (9.3\%) or included as part of the "Intended use" (3.1\%) (see Table 27).

Table 26

Learning Goals

\begin{tabular}{|c|c|c|}
\hline Learning goals & Total & $\%$ \\
\hline No & 78 & 71.9 \\
\hline Yes & 32 & 29.1 \\
\hline
\end{tabular}

Table 27

Location of Learning Goals

\begin{tabular}{|l|c|c|}
\hline \multicolumn{1}{|c|}{$\begin{array}{c}\text { Location of the } \\
\text { learning goal }\end{array}$} & Total & $\%$ \\
\hline In the Description & 13 & 40.6 \\
\hline Learning objectives/goals & 12 & 37.5 \\
\hline Intended/Suggested use & 3 & 9.3 \\
\hline $\begin{array}{l}\text { Instruction/ } \\
\text { Methodology/Pedagogy }\end{array}$ & 3 & 9.3 \\
\hline Other metadata & 1 & 3.1 \\
\hline TOTAL & 32 & \\
\hline
\end{tabular}

Most of the ROER that excluded metadata on learning goals (55 out of 78) did not contain any other specific metadata on education. In contrast, ROER with learning goals as a descriptor also included other educational metadata (in 10 out 12) and used educational metadata standards (in 8 out of 12).

Finally, by crossing all the proposed educational indicators (Table 28), educational aspects were found to have a higher incidence (with notable increases in educational metadata, which were present in over $60 \%$, and in learning goals in OER-exclusive repositories and a lower presence (all below 50\%, except the type of OER) with respect to the total ROER.

Table 28

Indicators of Educational Aspects 


\begin{tabular}{|l|c|c|c|c|c|}
\hline \multicolumn{1}{|c|}{$\begin{array}{c}\text { INDICATORS OF } \\
\text { EDUCATION ASPECTS }\end{array}$} & \multicolumn{2}{|c|}{$\begin{array}{c}\text { Total ROER } \\
(\mathbf{1 1 0 )}\end{array}$} & \multicolumn{2}{c|}{$\begin{array}{c}\text { Total OER-exclusive } \\
\text { repositories (60) }\end{array}$} & $\begin{array}{c}\text { \% Difference } \\
\text { (OER-exclusive vs. } \\
\text { Total ROER) }\end{array}$ \\
& Number & $\%$ & Number & $\%$ & \\
\hline Type of OER & 94 & 85.5 & $\mathbf{5 0}$ & $\mathbf{8 3 . 3}$ & -2.1 \\
\hline Educational metadata & 47 & 42.7 & $\mathbf{3 7}$ & $\mathbf{6 1 . 7}$ & $\mathbf{1 8 . 9}$ \\
\hline Learning goals & 32 & 29.1 & 26 & 43.3 & $\mathbf{1 4 . 2}$ \\
\hline Education standards & 22 & 20 & 18 & 30 & 10 \\
\hline
\end{tabular}

\section{Level of Development of ROER}

Using the incidence of indicators of reuse and educational issues in ROER, we could identify the level of development of these repositories and establish four main types (Table 29).

A. Top ROER: those that include 9 or 10 of the indicators (4 ROER). Only a few ROER intensively promoted reuse and educational aspects: Merlot (all 10 indicators) and OER Commons, UNIT and TEMOA (all three covered 9 of the 10 indicators).

B. High ROER: those that include 7 or 8 of the total indicators (9 ROER). These repositories had a substantial presence in social networks, were OER type, and included educational metadata, open licenses and quality assurance. None of these repositories had open formats. The ROER in this category are: Banco de Objetos de Aprendizaje Colombia Aprende, BOB, NDLR, Prometheat, OpenLearn, ATE Central, CURVE Open, Open SHNH and Banco Internacional de Objetos Educacionais.

C. Medium ROER: those that include 5 or 6 of the total indicators (31 ROER). The pattern is similar to that of High ROER, but the figures are considerably lower for some indicators, such as educational metadata.

D. Low ROER: those that include 1 to 4 of the total indicators (66 ROER). In general, the figures for all the indicators were much lower, and in particular they lacked (or had more deficiencies in) open formats, granularity, learning goals and educational standards.

Forty-four ROER ( $40 \%$ of the total) were placed in the top, high and medium categories, with different grades of promotion of reuse and educational features. However, the remaining 66 ROER, which make up the bulk of the population (60\%), do not have enough drivers to facilitate reuse and educational issues. 
Table 29

Categorization of ROER According to the Incidence of Reuse and Educational Indicators

\begin{tabular}{|c|c|c|c|c|c|c|c|c|c|c|c|}
\hline \multicolumn{2}{|c|}{$\begin{array}{l}\text { TOTAL OF ROER } \\
\text { (BY LEVEL) }\end{array}$} & $\begin{array}{l}\text { Intentionality } \\
\& \text { versioning }\end{array}$ & $\begin{array}{c}\text { Open license } \\
\text { or CC }\end{array}$ & Granularity & $\begin{array}{c}\text { Open } \\
\text { formats }\end{array}$ & Quality & $\begin{array}{c}\text { Social } \\
\text { interaction }\end{array}$ & $\begin{array}{l}\text { OER } \\
\text { types }\end{array}$ & $\begin{array}{l}\text { Educational } \\
\text { standard }\end{array}$ & $\begin{array}{l}\text { Educational } \\
\text { metadata }\end{array}$ & $\begin{array}{l}\text { Learning } \\
\text { goals }\end{array}$ \\
\hline \multirow{2}{*}{ TOP } & \multirow{2}{*}{4} & 4 & 4 & 4 & 2 & 4 & 4 & 4 & 3 & 4 & 4 \\
\hline & & $100 \%$ & $100 \%$ & $100 \%$ & $50 \%$ & $100 \%$ & $100 \%$ & $100 \%$ & $75 \%$ & $100 \%$ & $100 \%$ \\
\hline \multirow{2}{*}{ HIGH } & \multirow{2}{*}{9} & 6 & 8 & 5 & 0 & 8 & 9 & 9 & 3 & 9 & 7 \\
\hline & & $66.7 \%$ & $88.9 \%$ & $55.6 \%$ & 0 & $88.9 \%$ & $100 \%$ & $100 \%$ & $33.3 \%$ & $100 \%$ & $77.8 \%$ \\
\hline \multirow{2}{*}{ MEDIUM } & \multirow{2}{*}{31} & 18 & 20 & 10 & 5 & 19 & 20 & 22 & 8 & 19 & 13 \\
\hline & & $58.1 \%$ & $64.5 \%$ & $32.3 \%$ & $16.1 \%$ & $61.3 \%$ & $64.5 \%$ & $71 \%$ & $25.8 \%$ & $61.3 \%$ & $41.9 \%$ \\
\hline \multirow{2}{*}{ Low } & \multirow{2}{*}{66} & 12 & 37 & 4 & 2 & 16 & 34 & 55 & 5 & 11 & 5 \\
\hline & & $18.2 \%$ & $56.1 \%$ & $6.1 \%$ & 3 & $24.2 \%$ & $51.5 \%$ & $83.3 \%$ & $7.6 \%$ & $16.7 \%$ & $7.6 \%$ \\
\hline
\end{tabular}

An initial table was used to classify ROER according to the incidence of reuse and educational indicators. It contained the population of 110 ROER in the X-axis, and the 10 assessment indicators in the Y-axis: 6 on reuse (intentionality \& versioning, open licenses or CC, granularity, open formats, quality and social networks) and 4 on educational aspects (OER type, educational standard, educational metadata and learning goals). A second table, presented above, was drawn up to cluster similar ROER (those which included more or fewer indicators) and to identify the most popular indicators and the correlations between them. This is a basic, exploratory categorization that will be analyzed in greater depth in future research.

\section{Conclusions}

Based on the analysis, it has been found that most ROER on higher education are institutional (mainly created by universities and government bodies) and exclusively designed for educational resources, rather than hybrids that also contain research content. Considering that OER production remains essentially linked to public funding, international projects and institutions (Castaño et al., 2016), it makes sense that OER production has no place outside of institutional funding. This is particularly true when there are few rewards for OER

The main current features identified in ROER for promoting reuse are open licenses (specifically CC) and social networks. Intentionality, versioning and quality lag behind, and granularity and open formats are less evident. This suggests that repositories focus more specifically on OA licensing for OER and on taking care of or facilitating the creation of communities of users, who, in turn, could offer additional bottom-up quality criteria for deposited content. The reuse promotion pattern was slightly different in ROER created specifically to deposit OER. The open licensing indicator remained important, and the social network aspect increased considerably. In addition, quality and granularity began to play a more prominent role. Therefore, OER-exclusive repositories include a wider range of features, and use them more intensively, to facilitate the reuse of their resources.

The most prevalent educational aspects offered in ROER are content type, format and subject. However, 
less than half of ROER provide specific metadata related to education, and just over one quarter include learning goals. In addition, the few ROER that provide educational metadata do not always use a specific educational standard such as LOM or SCORM, which were developed to better identify the pedagogical properties of OERs. However, some do incorporate LOM elements in other default metadata specifications, such as Dublin Core. This could be because many institutional repositories use DC as a general schema for describing their resources, since they were created to store not only educational material, but also research or other types of content.

We could assume that educational features are more present in OER-exclusive repositories, which are created to meet an educational need. However, such repositories are not currently achieving their fullest potential. Although there is more educational information in this kind of repository (just over sixty per cent), there are still many cases of OER described and retrieved by type or format instead of by detailed educational metadata that better meets the users' needs, for example the suggested use of content, its duration, pedagogy, target audience or learning goals.

To sum up, current ROERs include more drivers that promote the reuse of OERs, mainly through open licenses and social networks, than features facilitating the retrieval and use of OERs according to educational needs, such as learning goals.

A level of development of ROER was identified, based on the incidence of reuse and educational indicators. We identified four clusters of ROERs ranging from a small top level of repositories that include most of the reuse and educational dimensions to a large lower level of repositories that lack important features such as open formats, granularity and educational metadata. In the middle of this scale, we also identified a high category mainly characterized by providing social networks and educational metadata standards, and a medium category offering a diverse mix of indicators.

We summarize here some of our findings in relation to previous studies. Some similar trends were identified in the general description of the ROER: most of them were multidisciplinary, institutional, predominantly based in Europe and the USA, and supported by DSpace technology. However, there are also a few fine distinctions, in three particular areas: in the numbers, insofar as our data show a significant increase in institutional ROER; in location, given that Europe and especially the UK, Spain and France took precedence over the USA in our study, while other related work found the opposite situation; and finally in technical infrastructure, where in line with other recent studies and in contrast to previous studies, our findings show an emerging tendency to adopt CMS.

Some differences were also observed with respect to prior works. While our results showed a clear predominance of Dublin Core above other specifically educational metadata specifications, other studies found an opposite pattern or simply did not specify the metadata schema used by the ROER. Other differences observed in our research were increased openness in ROER and a more intensive use of CC licenses overall in areas with higher numbers of ROER, such as Europe and the USA.

Finally, some of our main contributions were that OER-exclusive repositories led to better reuse and educational outcomes than hybrids and that most of the CC licenses used in ROER allowed reuse, as there was a notable presence of BY-NC-SA and BY-NC. This achievement, added to the use of other kinds of open license, shows increased openness of ROERs. 
To further develop the research, the evaluation framework could be expanded by adding features, and the categorization of ROER could be examined in greater depth. The research could use indicators that are more focused on pedagogy and bottom-up approaches, as these increase the educational usefulness of ROER and the reuse of OER. Additional features could be based on users' interaction, meaning communities and personal spaces, kind of information shared, social tagging procedures, etc., and types of OER, defined by whether the material was produced by students or educators and who it is aimed at (students, teacher trainers, the OER community, learning innovators). Users' participation helps to evaluate and license the stored OER, which facilitates reuse and makes it easier to integrate educational needs into the classification and retrieval process.

\section{Acknowledgements}

This study was carried as part of the project "Open Access to Science in Spain" (CSO2014-52830-P) of the Spanish R\&D Plan, funded by the Spanish Ministry of Science and Innovation.

\section{References}

Alexopoulos, A. D., Solomou, G. D., Koutsomitropoulos, D. A., \& Papatheodorou, T. S. (2010). Enhancing digital repositories with learning object metadata. In Lazarinis, Green, \& Pearson (Eds.), Handbook of research on e-Learning standards and interoperability: frameworks and issues (pp.246-263). DOI: 10.4018/978-1-61692-789-9

Al-Khalifa, H., \& Davis, H. (2006). The evolution of metadata from standards to semantics in Elearning applications. In Proceedings of the Seventeenth Conference on Hypertext and Hypermedia, (pp. 69-72). New York: ACM Press. DOI: 10.1145/1149941.1149956

Allen, N., Browne, D., Forward. M. L., Green, C., \& Tarkowski, A. (2015). Foundation for OER strategy development (Electronic document). Retrieved from http://www.oerstrategy.org/home/readthe-doc/

Amiel, T., \& Soares, T. (2016). Identifying tensions in the use of open licenses in OER repositories. The International Review of Research in Open and Distributed Learning, 17(3). DOI: http://dx.DOI.org/10.19173/irrodl.v17i3.2426

Atenas, J. \& Havemann L. (2013). Quality assurance in the open: An evaluation of OER repositories. The International Journal for Innovation and Quality in Learning, 1(2), 22-34. Retrieved from http://eprints.soas.ac.uk/17347/1/30-288-1-PB.pdf

Barrueco, J.M.; De Miguel, M.; González, C \& Rico-Castro, P. (2014). Guía para la evaluación de repositorios institucionales de investigación (Guide for the evaluation of institutional 
research repositories). Madrid. Retrieved from http://hdl.handle.net/10272/11370

Bissell, A. (2011). OER and Open License: the dual-pub solution. The Monterey Institute for Technology and Education. Retrieved from https://oerknowledgecloud.org/sites/oerknowledgecloud.org/files/59893035-OER-andOpen-Licenses-Dual-Pub-Solution.pdf

Bueno-de-la-Fuente, G., Hernández-Pérez, T., Rodríguez-Mateos, D., Méndez-Rodriguez E., \& MartínGalán B. (2009). Study on the use of metadata for digital learning objects in University institutional repositories (MODERI). Cataloging \& Classification Quarterly, 47(34), 262-285. DOI: 10.1080/01639370902737315.

Camilleri, A. F., Ehlers, D. U., \& Pawlowski, J. (2014). State of the art review of quality issues related to Open Educational Resources (OER) (JRC Science for Policy Report). DOI: http://dx.doi.org/10.2791/80171

Castaño, J., Punie, Y., Inamorato, A., Mitic, M., \& Morais, R. (2016). How are higher education institutions dealing with openness? A survey of practices, beliefs and strategies in five European countries (JRC Science for Policy Report). DOI: 10.2791/709253

Cervone, H. F. (2011). Digital learning object repositories. OCLC systems \& services: International Digital Library Perspectives, 28(1), 14-16. DOI: 10.1108/10650751211197031

Chatzinotas, S., \& Sampson, D. (2005). Exploiting the learning object paradigm for supporting webbased learning communities. Proceedings of the 4th IASTED International Conference on Web-based Education (pp. 165-170), Switzerland: ACTA Press.

Clements, K. (2016). Why Open Educational Resources repositories fail? The contribution of quality approaches to the success of repositories. University of Jyväskylä. Retrieved from http://urn.fi/URN:ISBN:978-951-39-6588-4

Clements, K., Pawlowski, J., \& Manouselis, N. (2015). Open Educational Resources repositories literature review-Towards a comprehensive quality approaches framework. Computers in Human Behavior, 51, 1098-1106. DOI: 10.1016/j.chb.2015.03.026

Cohen, A., Reisman, S., \& Bied Sperling, B. (2015). Personal spaces in public repositories as a facilitator for Open Educational Resource usage. The International Review of Research in Open and Distributed Learning, 16(4). Retrieved from http://www.irrodl.org/index.php/irrodl/article/view/2399 
D'Antoni, S. (2007). Open Educational Resources and open content for higher education. RUSC. Universities and Knowledge Society Journal, 4(1). DOI: https://doi.org/10.7238/rusc.v4i1.292

D’Antoni, S. (2013). A world map of Open Educational Resources initiatives: Can the global OER community design and build it together? Summary report of an international conversation. OER KnowledgeCloud. Retrieved from https://oerknowledgecloud.org/?q=content/worldmap-open-educational-resources-initiatives-can-global-oer-community-design-and-build-i

De los Arcos, B., Farrow, R., Perryman, L. A., Pitt, R., \& Weller, M. (2014). OER evidence report 20132014. OER Research Hub. Retrieved from http://oro.open.ac.uk/41866/1/oerrh-evidencereport-2014.pdf

Dichev, C., \& Dicheva, D. (2012). Is it time to change the OER repositories role? In Proceedings of the 12th ACM/IEEE-CS Joint Conference on Digital Libraries (JCDL 2012). Washington, DC, USA.

European Commission. (2013a). Communication from the Commission to the European Parliament. Opening up education: Innovative teaching and learning for all through new technologies and Open Educational Resources. Retrieved from http://eur-lex.europa.eu/legalcontent/EN/TXT/PDF/?uri=CELEX:52013DC0654\&from=EN

European Commission (2013b). Analysis and mapping of innovative teaching and learning for all through new technologies and Open Educational Resources in Europe. Retrieved from http://eur-lex.europa.eu/legalcontent/EN/TXT/?qid=1389115521455\&uri=CELEX:52013SC0341

European Commission (2014). Report on progress in quality assurance in higher education. Retrieved from http://ecahe.eu/assets/uploads/2014/01/EU-Report-on-Progress-in-QualityAssurance-in-Higher-Education-2014.pdf

Fulantelli, G., Gentile, M., Taibi, D., \& Allegra, M. (2008). The Open Learning Object model to promote Open Educational Resources. Journal of Interactive Media in Education, 2008(1). DOI: http://DOI.org/10.5334/2008-9

Gesser, G. (Ed., 2007). Open educational practices and resources. OLCOS Roadmap 2012 (PDF document). Retrieved from http://www.olcos.org/cms/upload/docs/olcos roadmap.pdf

Godby, C., Young, J., \& Childress, E. (2004). A Repository of Metadata Crosswalks. DLib Magazine, 1O(12). DOI: 10.1045/december2004-godby.

Hylén, J., Damme, D. V., Mulder, F., \& D’Antoni, S. (2012). Open Educational Resources: Analysis of responses to the OECD country questionnaire. OECD Education Working Papers, 76. DOI: http://dx.DOI.org/10.1787/5k99orjhvtlv-en 
Jacobi, R., \& van der Woert, N. (2012, March). Trend report: Open Educational Resources 2012. Special Interest Report Open Educational Resources. Retrieved from https://www.surfspace.nl/media/bijlagen/artikel-697ee18acof1441bb158e6122818f5f58ge.pdf

Koutsomitropoulos, D. A., Alexopoulos, A. D., Solomou, G. D., \& Papatheodorou, T. S. (2010). The use of metadata for educational resources in digital repositories: practices and perspectives. D-Lib Magazine, 16(1). DOI: 10.1045/january2010-koutsomitropoulos

Krippendorff, K. (1980). Content analysis: An introduction to its methodology. London, Los Angeles: SAGE.

Lane, A., \& McAndrew, P. (2010). Are open educational resources systematic or systemic change agents for teaching practice? British Journal of Educational Technology, 41(6), 952-962.

Littlejohn, A. (2003). Issues in reusing online resources. In A. Littejohn (Ed.). Reusing online resources: A sustainable approach to elearning (pp. 1-8). London: Kogan Page.

Maina, M.F., \& Guàrdia, L. (2012). Creating OER for versioning: Experts and learners as knowledge contributors. In Proceeding of E-Learn: World Conference on E-Learning in Corporate, Government, Healthcare (pp. 250-259). AACE. Retrieved from https://www.learntechlib.org/p/41596

McGreal, R. (Ed.). (2004). Online education using learning objects. New York: RoutledgeFalmer.

McGreal, R. (2011). Open Educational Resource repositories: An analysis. Athabasca University. Retrieved from http://www.academia.edu/2832823/Open_educational_resource_repositories_An_analysis

McKerlich, R. C., Ives C., \& McGreal R. (2013). Measuring use and creation of open educational resources in higher education. The International Review of Research in Open and Distance Learning. 14(4), 91-102. Retrieved from https://oerknowledgecloud.org/content/measuringuse-and-creation-open-educational-resources-higher-education

Monge, S., Ovelar, R., \& Azpeitia, I. (2008). Repository 2.0: Social dynamics to support community building in learning object repositories. Interdisciplinary Journal of E-Learning and Learning Object, 4, 191-204.

Nair, S., \& Jeevan, V. (2004). A brief overview of metadata formats. DESIDOC Bulletin of Information Technology, 24(4), 3-11.

Neumann, J., \& Muuß-Merholz, J. (2016). OER Atlas 2016 Open Educational Resources: Akteure und Aktivitäten in Deutschland, Österreich und der Schweiz (Electronic document). Retrieved from https://oerworldmap.files.wordpress.com/2016/o3/oer-atlas-2016-komplett.pdf 
Ochoa, X., \& Duval, E. (2009). Automatic evaluation of metadata quality in digital repositories. International Journal on Digital Libraries, 10(67). DOI: 10.1007/s00799-009-0054-4

Organisation for Economic Co-Operation and Development. (2007). Giving knowledge for free: The emergence of open educational resources. Centre for Educational Research and Innovation. Paris. Retrieved from https://www.oecd.org/edu/ceri/38654317.pdf

Orr, D., Rimini, M., \& Van Damme, D. (2015). Open educational resources: A catalyst for innovation. Paris. DOI: http://dx.doi.org/10.1787/9789264247543-en

Palavitsinis, N., Manouselis, N., \& Sanchez-Alonso, S. (2014). Metadata quality in learning object repositories: A case study. The Electronic Library, 32(1), 62-82.

Pegler, C. (2011). Reuse and repurposing of online digital learning resources within UK higher education: 2003-2010 (Doctoral dissertation). The Open University. Retrieved from http://oro.open.ac.uk/32317

Rodríguez, J., Dodero J., \& Sánchez-Alonso, S. (2011). Determinando la relevancia de los recursos educativos abiertos a través de la integración de diferentes indicadores de calidad (Determining the relevance of open educational resources through the integration of different quality indicators). Revista de Universidad y Sociedad del Conocimiento, 8(2), 46-60.

Sampson, D., Zervas, P., \& Sotiriou, S. (2013). Sharing of open science education resources and educational practices in Europe. In R, McGreal, W. Kinuthia, \& S. Marshall (Eds.). Open educational resources: Innovation, research and practice, (pp. 105-121). Retrieved from https://oerknowledgecloud.org/sites/oerknowledgecloud.org/files/pub PS OERIRP web.pdf\#page $=131$

Santos-Hermosa, G., Ferran, N., \& Abadal, E. OER repositories. (2015, June 4-5). Characterisation and evaluation indicators. Poster session presented at the meeting of II Internationale Seminar on LIS Education and Research (LIS-ER), Barcelona, Spain. Retrieved from http://bd.ub.edu/liser/sites/bd.ub.edu.liser/files/posters/Poster_LISER_Santos\%252c\%20Ferran\%26Abadal def.pdf

Serrano, R., Melero, R., \& Abadal, E. (2014). Indicadores para la evaluación de repositorios institucionales de acceso abierto [Indicators for an Evaluation of Institutional Repositories of Open Access]. Anales De Documentación, 17(2). DOI: https://doi.org/10.6018/analesdoc.17.2.190821

Shmueli, E., \& Cohen, A. (2012). The usage of open educational resources in MAOR repository. The International Journal of Technology Enhanced Learning (IJTEL), 4(3), 284-298. DOI: 10.1504/IJTEL.2012.051552

Skourlas, C., Tsolakidis, A., Belsis, P., Vassis , D., Kampouraki , A., Kakoulidis, P., \& Giannakopoulos, A. (2016). Integration of institutional repositories and e-learning platforms for supporting disabled students in the higher education context, Library Review, 65(3), 136-159. 
Sicilia, M., García-Barriocanal, E., Sánchez-Alonso, S., \& Cechinel, C. (2010). Exploring user-based recommender results in large learning object repositories: The case of MERLOT. Procedia Computer Science, 1, 2859-2864.

Tzikopoulos, A., Manouselis, N., \& Vuorikari, R. (2007). An overview of learning object repositories. In P. Taylor Northrup (Ed.), Learning objects for instruction: Design and evaluation (pp. 2955). IGI Global. DOI: 10.4018/978-1-59904-334-0.choo3

UNESCO. (2011). Guidelines for open educational resources (OER) in higher education. Retrieved from http://unesdoc.unesco.org/images/0021/002136/213605e.pdf

Venturini, J. (2014). Recursos educacionais abertos no Brasil: O campo, os recursos e sua apropriação em sala de aula (Open Educational Resources in Brasil: The field, the resources and its appropriation in the classroom). Questão, 11. Retrieved from http://www.acaoeducativa.org/images/stories/pdfs/EmQuestao11_site.pdf

Westell, M. (2006). Institutional repositories: Proposed indicators of success. Library Hi Tech, 24(2), 211-226. http://www.acaoeducativa.org/images/stories/pdfs/EmQuestao11 site.pdf

Wharrad, H., \& Windle, R. (2010). Case studies of creating reusable inter professional e-learning objects. In A. Bromage, L. Clouder, J. Thistlethwaite, \& F. Gordon (Eds.). Interprofessional elearning and collaborative work: practices and technologies. IGI Global (pp. 260-274).

Wiley, D. A. (2000). Connecting learning objects to instructional design theory: A definition, a metaphor, and a taxonomy.In D. A. Wiley (Ed.). The instructional use of learning objects. Open Publication License. Retrieved from http://reusability.org/read/chapters/wiley.doc

Wiley, D., Bliss, T. J., \& McEwen, M. (2014). Open educational resources: A review of the literature. In J. M. Spector, M. D. Merrill, J. Elen \& M. J. Bishop (Eds.). Handbook of research on educational communications and technology (pp. 781-789). New York: Springer. DOI: 10.1007/978-1-4614-3185-5_63

Wills, S., \& Pegler, C. (2016). A deeper understanding of reuse: learning designs, activities, resources and their contexts. Journal of Interactive Media in Education. 2016(1). DOI: http://DOI.org/10.5334/jime.405

Windle, R. J., Wharrad, H., McCormick, D., Laverty, H., \& Taylor, M. G (2010). Sharing and reuse in OER: experiences gained from open reusable learning objects in health. Journal of Interactive Media in Education, 2010(1), 4. DOI: http://DOI.org/10.5334/2010-4

Yalcinalp S., \& Emiroğlu, B. G. (2012). Through efficient use of LORs: Prospective teachers' views on operational aspects of learning object repositories. British Journal of Educational Technology, 43(3), 474-484. DOI: 10.1111/j.1467-8535.2011.01212.x 
Zancanaro, A., Todesco, J., \& Ramos, F. (2015). A bibliometric mapping of open educational resources. The International Review of Research in Open and Distributed Learning, 16(1). DOI: http://dx.DOI.org/10.19173/irrodl.v16i1.1960

Zervas, P., Alifragkis, C. \& Sampson, D. G. (2014). A quantitative analysis of learning object repositories as knowledge management systems. Knowledge Management \& E-Learning, 6(2), 156-170.

\section{Athabasca}

University

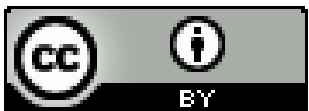

